Суб'єкти готельного ринку потребують професійного підходу до формування та управління бізнес-процесами відповідно до вимог і тенденщій корпоративного співробітництва та стандартів якості послуг і відносин, щу гарантує комплаєнс-контроль.

Посилено сертифікацію і стандартизацію діяльності та послуг серед закладів розміщення, пов'язаних з питаннями безпеки споживачів та конкурентоспроможності як у національній, так і світовій туристичній системі.

Висновки. Виявлення рівня комплаєнс-контролю уможливлює визначення рівня відповідальності системи управління та керованості системою якості.

Описані аналітичні методи формування та оцінки рівня комплаєнс-контролю діяльності готельних підприємств формують чітку систему відповідності стандартам, правилам, вимогам томо, визначення ефективності яких стане предметом подальших досліджень.

Ключові слова: готель, комплаєнс, комплаєнс-контроль, комплаєнс-ризики.

UDC 005.334=111

MATUSOVA Olena,

$\mathrm{PhD}$, Associate Professor of Department of Economics and Business Finance

Kyiv National University of Trade and Economics 19, Kyoto str., Kyiv, 02156, Ukraine

E-mail: o.matusova@knute.edu.ua ORCID: http://orcid.org/0000-0001-7998-3289
DOI: http://doi.org/10.31617/visnik.knute.2019(128)07

YAHODZINSKY Viktor, $\mathrm{PhD}$, Director of "DQS Certific Ukraine" 6-d, Mykola-Slobidska str., Kyiv, 02002, Ukraine

E-mail:yavik22@ukr.net

\title{
RISK MANAGEMENT MODELS
}

The basic business processes of the enterprise that are the basis for building a risk management system are identified. The main components of the enterprise risk management model have been established in accordance with the planning, operation and control of the enterprise activity. Based on the proposed model, risk identification techniques and key indicators that influence the performance of risk analysis and management at the enterprise are identified. on risk.

Keywords: risk, risk management, model, business processes, risk analysis, impact

(C) Matusova O., Andryeyeva V., Yahodzinsky V., 2019

ISSN 1727-9313. HERALD OF KNUTE. 2019. NN 6 
Матусова Е., Андреева В., Ягодзинский В. Модели риск-менеджмента. Определены основные бизнес-прочессы предприятия, которые являются базисом для построения системы управления рисками. Установлены главные компоненты модели управления рисками на предприятии в соответствии с планированием, функиионированием и контролем деятельности предприятия. На основе предложенной модели определены методики идентификации риска, ключевые индикаторы, влияющие на результативность анализа и обработку рисков на предприятии.

Ключевые слова: риск, управление рисками, модель, бизнес-процессы, анализ риска, влияние на риск.

Background. The synergistic properties inherent in an enterprise management system that meets the requirements of different standards and models and satisfies the requirements of all stakeholders is the main subject of research into the constant development of an entity.

Each enterprise seeks to maintain its own position, despite the current economic crisis and adverse market conditions. Therefore, in addition to meeting the formal requirements of the standards, it is vital for stakeholders to ensure business continuity, that is, to maintain the ability to provide services or produce products to consumers before, during and after a crisis. To this end, management should analyze possible business impacts for prioritizing business functions based on an assessment of the potential financial and non-financial risks that threaten business continuity. To ensure safe, effective and timely action, the priority areas are: protection of human life; protection of business assets; support or early recovery of key business processes.

On the way to achieving the set goals, the company faces internal and external influences that create uncertainty about their timely reach. Therefore, for businesses seeking sustainable development in a complex, everchanging environment, it is important not so much to establish the compliance of the management system with the requirements of different standards as to obtain comprehensive risk information in all areas of activity of the entity. Therefore, the introduction and continuous improvement of the risk management system in the enterprise is a prerequisite for its competitiveness and timely response to the challenges of the changing environment.

Risk management is seen as a process that operates on certain principles: it is continuous and covers the whole enterprise; carried out at all levels and in all departments of the enterprise used in strategy development and formulation; aimed not at specific risk but at their complex, considering the possibility of mutual influence of risks on each other and occurrence of synergism effect, detection of events in such a way that the organization could take risk without threat of liquidation; provides management with a sound guarantee of achieving goals even in times of crisis [1].

Analysis of recent research and publications. Issues related to the consideration of such concepts as: "risk", "uncertainty", "risk management" were investigated by N. Khrushch, M. Nastenko, M. Cruy, M. Velikanova, O. Gerasimenko [1-5] etc. 
Although the problems of providing an effective enterprise management system are actively discussed by politicians, scientists, practitioners of various spheres of public activity, not all aspects in this sphere have sufficient theoretical and methodological elaboration. These include the identification, assessment, counteraction to risks and threats to the economic activity of the enterprise, as well as the formation of a modern model of enterprise risk management.

The aim of the article is to develop a model of risk management as an integral part of the enterprise management system, which will ensure its effective operation in modern conditions of changing internal and external environment and meeting the needs of all interested stakeholders.

Materials and methods. Dialectical cognition method, methods of analysis, synthesis, system and process approach, as well as modeling of business processes were used to build a risk management model at the enterprise.

Results. The global experience of risk management shows that the main principle of modernization of risk management was the principle of quality management system [6], which involves the application of a process approach to management on the basis of continuity, involvement of the whole organization, taking into account its goals, effective communication between management entities, and also giving preference to preventive measures (figure 1).
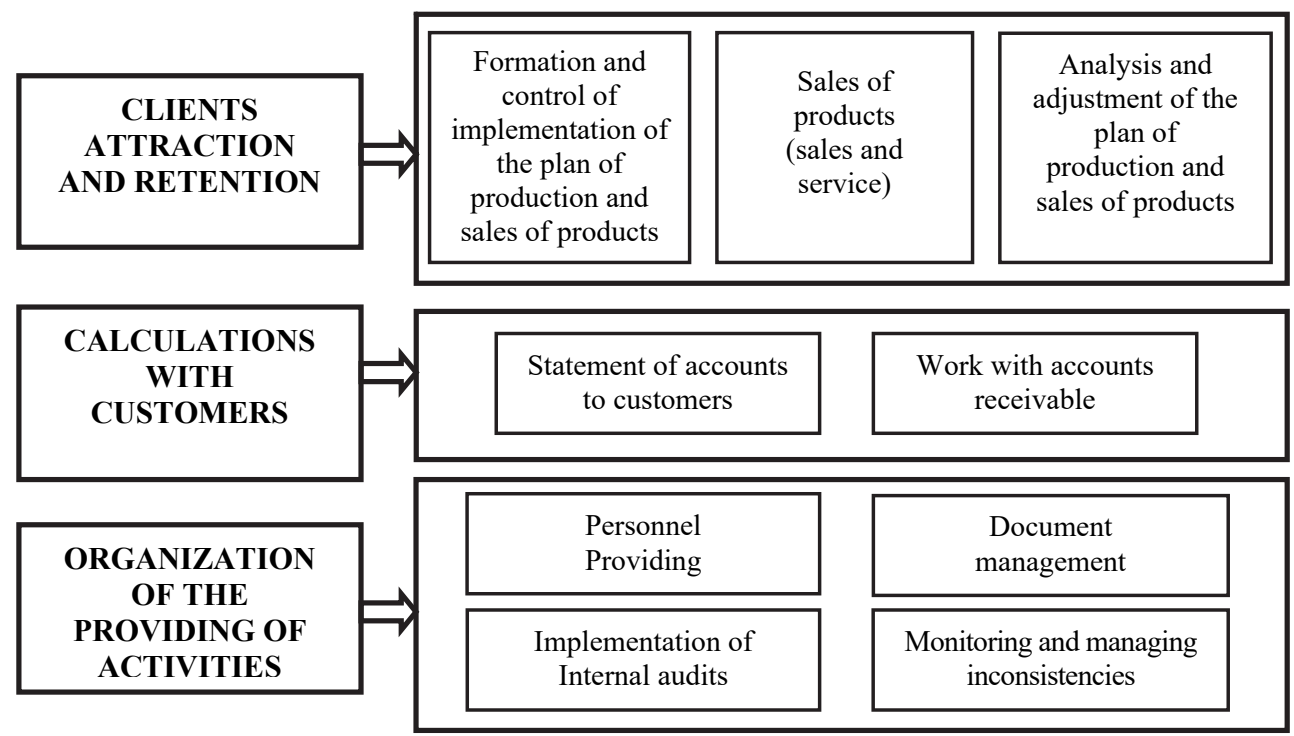

Figure 1. The main processes of the enterprise

Source: developed by the authors.

An enterprise trying to respond to changes in the market can be guided in its activity by dividing into the key processes outlined in figure 1 . It is these processes and changes in them that provide the basis for functioning and stimulate its development, and are crucial for establishing the mission and main goals of the enterprise. Thus, risk management as a response to changes in the processes of the enterprise is a necessary prerequisite for achieving the planned level of performance.

ISSN 1727-9313. HERALD OF KNUTE. 2019. 
ISO 31000: 2018 establishes principles, a common framework for risk management, that can reduce the risk of failure to meet targets in a timely manner:

- implementing risk-oriented thinking in the organization;

- risk identification and management;

- improvement of enterprise management in general [7;8].

By improving risk management approaches, the company expands opportunities for improvement and innovation, as well as shortening the timeframe for achieving its goals. Risk assessment information provides objective, comprehensive input for critical analysis of management by Board and decision making and actions related to: improving system performance; product/ service improvement; reducing the risk of dissatisfaction with all stakeholders.

In order to obtain comprehensive information about the management system, which contains information not only about the non-compliance of this system with certain points of international standards, but also about possible cause and effect relationships of systemic problems, it is of fundamental importance for the maturity of the organization at the moment of searching for new approaches to improving the management system, as well as management system goals set by senior management.

In accordance with the process approach and the approved world standards, in order to ensure the effectiveness of the risk management system at the enterprise, a risk management model is being built, which contains three main components, which correspond to the basic elements of the enterprise's activity (figure 2).

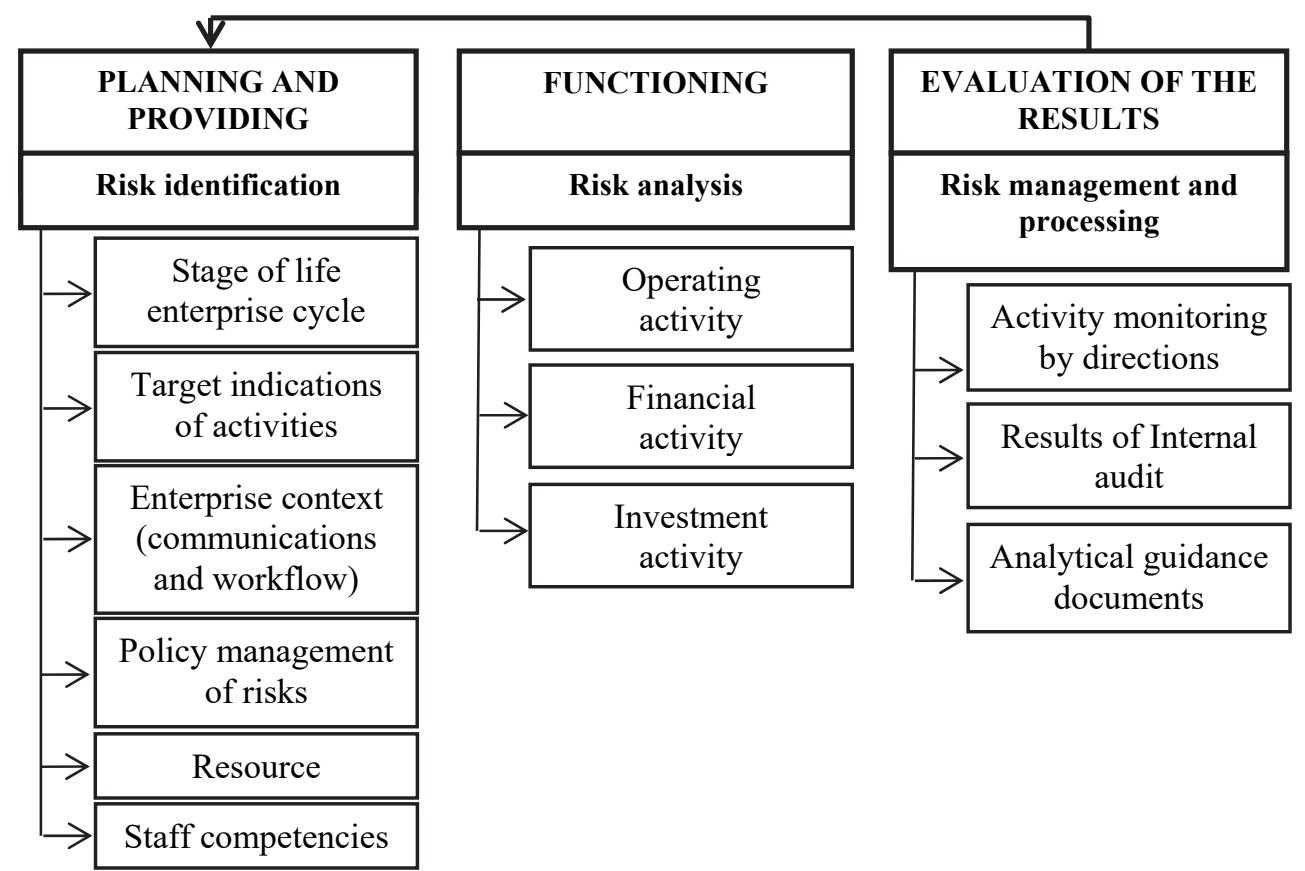

Figure 2. Model of risk management in the enterprise

Source: developed by the authors. 
The component of the "Risk Identification" model provides the basis for further risk analysis and identifies the main factors of the internal and external environment that may be the reasons of risk situations.

To identify risks, an entity can use two main methods or its combination: proactive and responsive.

The proactive method is implemented by means of detailed functional analysis of business processes before the fact of deviations of the final results. To perform this analysis, it is necessary to decompose the process into elementary components. An elementary component is a simple action or function that can be described by a single verb in a commanding manner. The inputs, resources, controls, and outputs that lead to the end result of the process should be identified, unless otherwise specified in the relevant enterprise regulations.

The next step is to identify the events and conditions that may occur:

- a common factor of danger;

- components of the danger factor;

- probable conditions, events that may occur;

- the consequences that each component of a dangerous factor can lead to when each condition and event occurs.

For the proactive method, it is recommended to use SWIFT - Structured "What-if" Technique. By this method, risks are identified through the formulation of the questions "What if?", "What happens if?", which allows us to investigate the impact of uncertain conditions and events on the process.

Reacting technique is based on deviations that have already occurred. The analysis is performed, the causes and conditions that led to a particular event are determined. At this stage, the use of the "5 WHYS?" Technique is envisaged. The 5 WHYS technique ("What?", "Who?", "Where?", "When?", "How?") is set to investigate the reasons of the appearance by finding the answer to the question "Why (appearance)?":

- this rejection;

- reasons for rejection;

- events that are the reasons;

- conditions are heralds of events.

The analysis of deviations of process outcomes from established indicators and risk identification should be carried out with the participation of employees who have sufficient knowledge, practical experience and thorough understanding of all details of the process. A flowchart of the risk analysis and risk assessment sub-process is presented in the figure 3 .

The source for risk analysis is any information about unforeseen events that occurred at the enterprise. Sectoral information on similar events is also possible.

The following questions can be used to determine the probability of a risk:

- Have events in the past been similar to the one under consideration, or is this an isolated incident?

- What other processes or components of the same type might have similar deviations? 
-What is the number of employees who perform these procedures?

- What percentage of the time during the process or procedure is in doubt?

- How serious are the organizational or managerial implications that could indicate more significant factors for the occurrence of deviations?

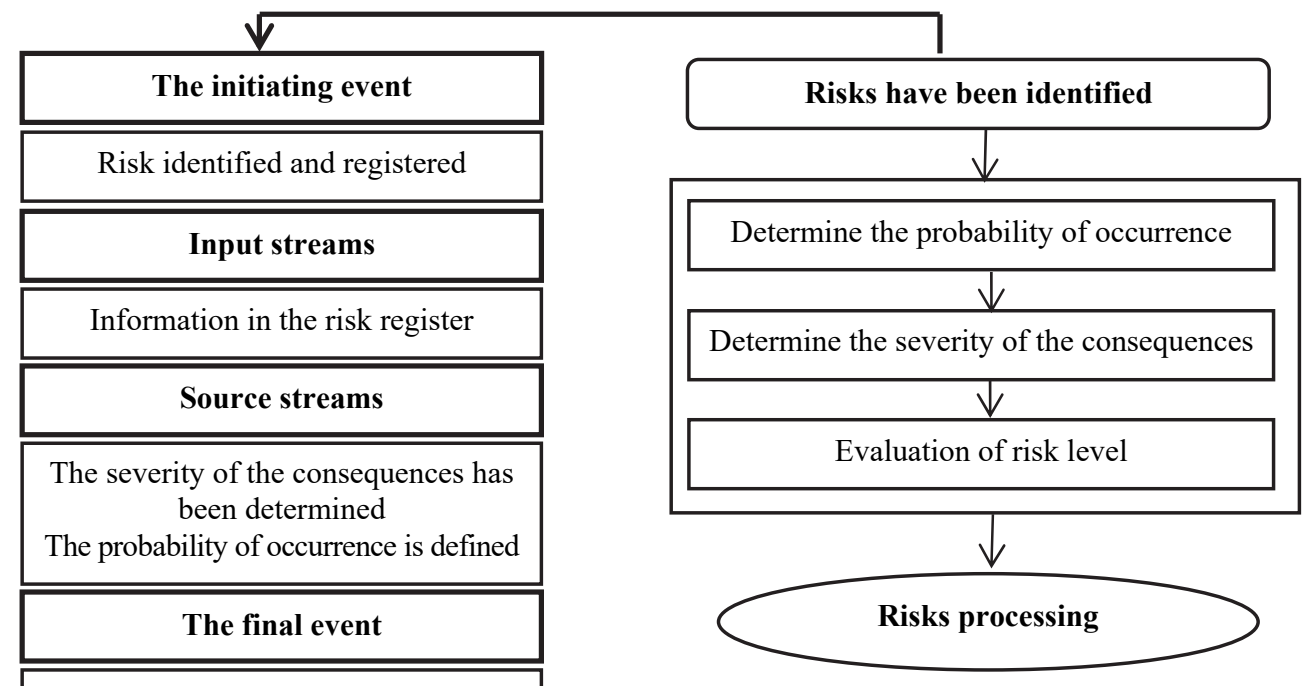

The level of risk is defined

Figure 3. Analysis and evaluation of results at the enterprise

Source: developed by the authors.

Assessing the possibility that an undetermined event or condition may occur, it is crucial for informed decisions to look back over the years. In the absence of such information, risk estimation is allowed based on industry trends or expert opinion.

The risk probability matrix is presented in the table 1 .

Table 1

Matrix of probability of occurrence of risks in the enterprise

\begin{tabular}{|c|c|c|}
\hline $\begin{array}{c}\text { Frequency } \\
\text { of occurrence }\end{array}$ & Meaning & Degree \\
\hline Often & It can happen many times (happened often) & 5 \\
\hline Sometimes & Occasionally & 4 \\
\hline Very rare & Unlikely but possible that it will happen & 3 \\
\hline unlikely & It is very unlikely to happen (no details of what happened) & 2 \\
\hline It is highly unlikely & The possibility of an event is almost off & 1 \\
\hline
\end{tabular}

Source: developed by the authors.

The next step in the process of organizational control of the risk factors associated with the consequences of deviations is to assess the severity of the consequences if the damage materializes in the processes of production and marketing of products (provision of services). 
The severity of risk factors is defined as the possible consequences of an uncertain event or condition, with the worst case scenario being considered as the benchmark. These issues can, for example, help to assess the severity of the consequences if their potential materializes in the course of the enterprise's activities:

- What is the number of negative situations related to customer satisfaction?

- What is the level of damage to the enterprise (damage or destruction of the property of the enterprise, property of customers or external suppliers, damage to a third party, financial and economic consequences for the enterprise)?

- What is the probability of environmental impact (Dangerous Product Incidents or Other Environmental Disorders)?

- What is the probability of violations of current law?

- What is the level of harm to the health of customers, employees, etc?

Based on the content of the answers to such questions, one can estimate the severity of the possible consequences of an undetermined event or condition by using the risk factor matrix of severity while assuming the worst case scenario as a benchmark (table 2).

The Impact Severity Matrix contains five categories that characterize the severity of an undetermined event or condition. The value of each category assigned corresponds to the degree of severity of the undetermined state or event. Just like the probability matrix, this table is an example given to provide an algorithm to an expert team.

Table 2

Matrix of severity of consequences of risk exposure

\begin{tabular}{|c|l|c|}
\hline $\begin{array}{c}\text { Seriousness } \\
\text { of consequences }\end{array}$ & \multicolumn{1}{|c|}{ Meaning } & Degree \\
\hline Critical & $\begin{array}{l}\text { Full stop of the operating process. } \\
\text { Destruction of property, infrastructure. } \\
\text { Receiving losses over a long period. } \\
\text { Health damage, human casualties }\end{array}$ & A \\
\hline Dangerous & $\begin{array}{l}\text { Significant reduction of the "safety margin" of equipment } \\
\text { and damage to property. } \\
\text { Receiving losses for several consecutive periods. } \\
\text { High share of overdue accounts payable. } \\
\text { Stress or workload that can cause staff to fail in their tasks }\end{array}$ & B \\
\hline Intense & $\begin{array}{l}\text { Breach of contract obligations. } \\
\text { High share of overdue receivables. } \\
\text { The staff is not fully able to cope with adverse operating } \\
\text { conditions due to increased workload or due to conditions } \\
\text { that reduce the efficiency of work }\end{array}$ & C \\
\hline Insignificant & $\begin{array}{l}\text { Production restrictions, short-term downtime production } \\
\text { equipment. } \\
\text { The presence of illiquid inventory. } \\
\text { Insignificant interpersonal conflicts }\end{array}$ & D \\
\hline Miserable & $\begin{array}{l}\text { Unplanned short-term downtime of fixed assets not related } \\
\text { to operating activities. } \\
\text { Minor violations of the staff work schedule }\end{array}$ & E \\
\hline
\end{tabular}

Source: developed by the authors.

ISSN 1727-9313. HERALD OF KNUTE. 2019. 
To obtain a general risk index, it is necessary to combine the probability matrix and the consequence severity matrix into the risk assessment matrix (table 3).

Table 3

Risk assessment matrix at the enterprise

\begin{tabular}{|c|c|c|c|c|c|c|c|}
\hline \multirow{7}{*}{ 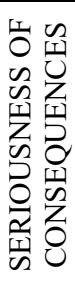 } & A & Critical & $1 A^{*}$ & $2 \mathrm{~A}^{* *}$ & $3 \mathrm{~A}^{* * *}$ & $4 \mathrm{~A}^{* * *}$ & $5 \mathrm{~A}^{* * *}$ \\
\hline & B & Dangerous & $1 \mathrm{~B}^{*}$ & $2 \mathrm{~B} * *$ & $3 \mathrm{~B} * *$ & $4 \mathrm{~B} * * *$ & $5 \mathrm{~B} * * *$ \\
\hline & $\mathrm{C}$ & Intense & $1 \mathrm{C}^{*}$ & $2 \mathrm{C}^{* *}$ & $3 C^{* *}$ & $4 C^{* *}$ & $5 \mathrm{C} * * *$ \\
\hline & $\mathrm{D}$ & Insignificant & $1 \mathrm{D}^{*}$ & $2 \mathrm{D}^{*}$ & $3 \mathrm{D}^{* *}$ & $4 D^{* *}$ & $5 \mathrm{D} * *$ \\
\hline & $\mathrm{E}$ & Miserable & $1 \mathrm{E}^{*}$ & $2 \mathrm{E}^{*}$ & $3 \mathrm{E}^{*}$ & $4 \mathrm{E}^{* *}$ & $5 \mathrm{E}^{* *}$ \\
\hline & & & $\begin{array}{c}\text { It is highly } \\
\text { unlikely }\end{array}$ & unlikely & Very rare & Sometimes & Often \\
\hline & & \multicolumn{6}{|c|}{ OBABILITY of occurrence } \\
\hline
\end{tabular}

* Indicates green (acceptable risks).

** Indicates yellow (risks that should be addressed in the medium term).

*** Indicated in red (risks need immediate response).

Source: developed by the authors.

A preliminary risk assessment is an alphanumeric combination and is not a visible or tangible component, so this combination is called $a$ risk index.

Acceptance zones are indicated by color marking in the risk assessment matrix (table 4). The risk index derived from the risk assessment matrix should now be transferred to the risk tolerance matrix, which characterizes the eligibility criteria.

Table 4

Summary matrix of risk levels at the enterprise

\begin{tabular}{|c|c|c|}
\hline Criterion & Risk Index & Level of risk \\
\hline $\begin{array}{c}\text { CRITICALLY } \\
\text { (Red colour) }\end{array}$ & 3A 4A 5A 4B 5B5C & $\begin{array}{c}1 \\
\text { Unacceptable }\end{array}$ \\
\hline $\begin{array}{c}\text { CONDITIONALLY } \\
\text { acceptably } \\
\text { (yellow) }\end{array}$ & 2A 2B2C 3B3C 3D 4C 4D 4E 5D 5E & $\begin{array}{c}2 \\
\text { Conditionally acceptable } \\
\text { (green) }\end{array}$ \\
\hline
\end{tabular}

Source: developed by the authors.

All risks exceeding the permitted limits must be processed. At the initial stage of settlement it is necessary to analyze the possibility of eliminating a dangerous factor - a source of risk. The further action is to analyze the possibility of avoiding the risk by ending the activity that causes it.

If the two previous steps for some reason are not acceptable to eliminate the risk, then it is necessary to proceed to the treatment of risk by influencing its determining parameters: reducing the probability of appearance and/or severity of consequences.

The processing of these parameters is possible through the development and implementation of measures aimed at increasing the probability of achieving the goals and reducing the probability of negative results of the process. The development of these measures should begin after an analysis of the potential impact on each parameter: 
probability of appearence: if the results of the analysis show the possibility of reducing the probability of occurrence, then appropriate measures should be taken;

severity of consequences: if the results of the analysis show the possibility of reducing the severity of the consequences, then it is necessary to develop measures that will result in their reduction, which will affect the variation of the final results of the processes.

Each action developed must be completed within the prescribed time. These actions should be a clearly defined plan of action, indicating the timing of each event and the responsible officials at each stage. The action plan must be approved by the head of the structural unit where the risk has been identified. In the event that several structural units are involved in the remedial action, a general action plan must be drawn up and agreed with the leaders involved.

After the implementation of the measures, a performance check should be carried out. If the actions taken did not reduce the parameters (probability and consequences), and the risk level to an acceptable level, then repeat the procedure.

Conclusion. In order to ensure timely response of the enterprise to the challenges of the changing environment, increase its competitiveness and economic security, it is necessary to apply a risk management model that must meet the world standards of risk management and key business processes of the enterprise. Such a model allows identification of risks, analysis of their consequences in two parameters and setting the procedure for their treatment.

Depending on the life cycle of the enterprise and the availability and completeness of the information base on the risk management process, each enterprise will not only have its own different model, but also apply different methods and approaches to risk identification, assessment and treatment. Identifications will also depend on the period of the risk event. If an entity is attempting to use preventive risk management measures, then a proactive risk identification technique will be effective, and if it is intended to evaluate the impact of the event on the entity's activities, then it is advisable to use a responsive methodology.

Risk analysis as an element of an enterprise risk management system will depend on a reliable and complete assessment of the two main risk parameters: the probability of occurrence and the consequences. The result of the analysis should be used to further influence the risk, the effectiveness of which, in turn, will also be determined by the level of involvement of all stakeholders.

\section{REFERENCES}

1. Hrushh, N. A., \& Docenko, I. O. (2016). Funkcional'ni osoblyvosti upravlinnja ryzykamy pidpryjemnyc'koi' dijal'nosti [Functional features of business risk management]. Visnyk Hmel'nyc'kogo nacional'nogo universytetu. Ekonomichni nauky - Journal of Khmelnitsky National University. Economics, 4(2), 268-272 [in Ukrainian]. 
2. Nastenko, M. M., Pokyn'chereda, V. V., \& Gudzenko, N. M. (2017). Koncepcija strategichnogo upravlinnja finansovymy ryzykamy pidpryjemstv [Concept of strategic management of financial risks of enterprises]. Visnyk Hmel'nyc'kogo nacional'nogo universytetu. Ekonomichni nauky - Journal of Khmelnitsky National University. Economics, 3(1), 18-22 [in Ukrainian].

3.Kruy, M., Galaj, D., \& Mark, R. (2014). Osnovy rysk-menedzhmenta [The basics of risk management]. V. B. Mynasjan (Ed.). Moscow: Jurajt [in Russian].

4. Velykanova, M. M. (2017). Vyjavlennja ta identyfikacija jak stadii' upravlinnja ryzykom [Detection and identification as a stage of risk management]. Chasopys Kyi'vs'kogo universytetu prava - Journal of the Kyiv University of Law, 3, 24-27. Retrieved from http://nbuv.gov.ua/UJRN/Chkup_2017_3_6 [in Ukrainian].

5. Gerasymenko, O. M., \& Zachosova, N. V. (2019). Ocinka rivnja zrilosti upravlinnja ryzykamy v procesi zabezpechennja ekonomichnoi' bezpeky pidpryjemstva: analitychne doslidzhennja [Assessment of the maturity level of risk management in the process of ensuring the economic security of the enterprise: an analytical study]. Visnyk Kyi'vs'kogo nacional'nogo universytetu tehnologij ta dyzajnu. Ekonomichni nauky - Journal of the Kiev National University of Technology and Design. Economic sciences, 3, 66-81 [in Ukrainian].

6. Upravlenie riskami organizacii: integrirovannaja model' [Organization Risk Management: An Integrated Model]. (n.d.). www.coso.org. Retrieved from http://www.coso.org/guidance.htm [in Russian].

7.Quality Management Principles. ISO 9001. www.iso.org. Retrieved from http://www.iso.org/iso/pub100080.pdf [in English].

8. ISO 31000 Risk Management. www.iso.org. Retrieved from https:/www.iso.org/ iso-31000-risk-management.html [in English].

The article submitted to editor's office on 18.11.2019.

Матусова О., Андрєєва В., Ягодзінський В. Моделі ризик-менеджменту.

Постановка проблеми. Підприємство, досягаючи свойх иілей, стикається з внутрішніми та зовнішніми впливами невизначеності. Тому важливо не лише встановити відповідність системи управління вимогам різних стандартів, а й отримати вичерпну інформацію про ризики у всіх сферах діяльності суб'єкта господарювання. Впровадження та постійне вдосконалення системи управління ризиками на підприємстві є необхідною умовою його конкурентоспроможності та своєчасного реагування на виклики середовищя.

Метою статті є розробка моделі управління ризиками як складової системи менеджменту на підприємстві, що забезпечить його ефективну діяльність у сучасних умовах мінливого внутрішнього і зовнішнього середовищ та задоволення потреб усіх зацікавлених сторін.

Матеріали та методи. Для побудови моделі управління ризиками на підприємстві використано діалектичний метод пізнання, методи аналізу, синтезу, системний та процесний підхід, а також моделювання бізнес-процесів.

Результати дослідження. Світовий досвід ризик-менеджменту засвідчує, щзо головним принципом модернізації управління ризиками став принцип застосування проиесного підходу. Відповідно до процесного підходу та затверджених світових стандартів для забезпечення ефективності функціонування системи ризик-менеджменту на підприємстві будується модель ризик-менеджменту, щзо містить три основні складові: ідентифікація ризику, аналіз та оиінка ризиків, влив на ризики. Компоненти моделі управління ризиками відповідають основним елементам функиіонування підприємства: планування та організація обслуговування, функціонування та контроль (оцінка ефективності управління ризиками на підприємстві). 
Підприємство може використовувати два основні методи ідентифікації ризиків: проактивний та реагуючий. 3 метою виявлення наслідків ризику аналіз ризику трунтується на оцінці двох показників (ймовірності та впливу). Усі існуючі ризики мають бути оброблені. Необхідно проаналізувати можливість усунення джерела ризику, після чого визначити можливості уникнення ризику шляхом припинення діяльності, яка його зумовлює.

Висновки. 3 метою забезпечення своєчасного реагування підприємства на виклики мінливого середовища, підвищення його конкурентоспроможності та економічної безпеки необхідно застосовувати модель управління ризиками, яка повинна відповідати світовим стандартам управління ризиками та ключовим бізнес-проиесам підприємства. Така модель дає змогу ідентифікувати ризики, проаналізувати їх наслідки за двома параметрами (ймовірність та вплив) та встановити процедуру впливу на них.

Ключові слова: ризик, управління ризиками, модель, бізнес-процеси, аналіз ризику, вплив на ризик.

\section{ZUBKO Tetiana,}

$\mathrm{PhD}$ (Economics), Associate Professor

of the Department of Economics and Business Finance

of Kyiv National University of Trade and Economics

19, Kyoto str., Kyiv, 02156, Ukraine

E-mail:t.zubko@knute.edu.ua

ORCID ID: https://orcid.org/0000-0002-8950-1797

\section{THE DIAGNOSIS OF ECONOMIC SECURITY OF THE ENTERPRISE}

The essence of economic security of the enterprise and methods of estimation of its level are considered. Methodical approaches to assessing the level of economic security of the enterprise are investigated, and their analysis is carried out. The system of functional components of economic security of the enterprise is proposed and the author's method of estimation of its level is substantiated.

Keywords: economic security, entrepreneurship, enterprise, indicators, hierarchy, thresholds, competitiveness.

(C) Zubko T., 2019 